\title{
On Gramsci and the international: a textual analysis
}

\author{
PETER IVES AND NICOLA SHORT*
}

\begin{abstract}
Antonio Gramsci's thought has strongly influenced the fields of IR and IPE through the work of Robert Cox, Stephen Gill, Kees van der Pijl and others, engagements often gathered (not uncontroversially) under the rubric of an ostensibly unified 'neo-Gramscian' position or 'the Italian School'. The emergence of such interventions into IR/IPE has sparked controversy regarding whether Gramsci's work can be legitimately applied to 'the international', both from within IR and in other fields. This article examines the validity of such critiques of 'neoGramscian IPE', which we argue rely on problematic characterisations and little evidence from Gramsci's writings. More substantively, we provide an exegesis of the role of the international dimension in the construction of central categories of Gramsci's thought and his approach to nation-state formation and international organisations such as the Catholic Church and the Rotary Club, which have been regrettably neglected by all facets of these discussions. We demonstrate that Gramsci can indeed be understood as a theorist of the international, whose approach is particularly salient for the present historical conjuncture.
\end{abstract}

Peter Ives is Associate Professor of Politics at the University of Winnipeg, Canada. He is author of Gramsci's Politics of Language: Engaging the Bakhtin Circle and the Frankfurt School (University of Toronto Press, 2004); Language and Hegemony in Gramsci (Pluto, 2004); and co-editor with Rocco Lacorte of Gramsci, Language and Translation (Lexington, 2010). His recent research project engages with the politics of language and global English appearing in Political Studies, Educational Philosophy and Theory, and Historical Materialism. He is a member of the editorial board of Rethinking Marxism and the collective of ARP Books. The author can be contacted at: \{p.ives@uwinnipeg.ca\}.

Nicola Short is Associate Professor of Political Science at York University, Toronto. Her work examines Gramscian theory particularly with respect to understanding neoliberalism in historical and material context. She is the author of The International Politics of Post-Conflict Reconstruction in Guatemala (Palgrave, 2007). The author can be contacted at: \{ncshort@yorku.ca $\geq$ \}

\section{Introduction}

The use of Gramsci's political theory to examine the 'international' has been the subject of a great deal of recent discussion. ${ }^{1}$ However, these discussions have tended to generate more heat than light. Much debate has been framed around the question

\footnotetext{
* An earlier version of this article was presented at the 7th Pan-European International Relations Conference, Stockholm (9-11 September 2010). The authors would like to thank David Ruccio and the three anonymous reviewers for their insightful comments.

1 We should note that some of the conceptual difficulty and cumbersome aspect of our topic comes from the very concept of 'international' (coined by Jeremy Bentham in 1780). This not only implies that global or worldwide relations and movements are confined to relations among pre-constituted nations it presupposes a national and international distinction without explicitly explaining it. This is the very question that many debates around the nation-state and globalisation revolve including whether
} 
of whether Gramsci's work can be 'internationalised' and whether those working in the so-called 'neo-Gramscian' school of International Political Economy (IPE) have appropriated Gramsci's concepts properly since, it is claimed, he developed his concepts and analysis from a fundamentally national perspective. There are two seemingly disparate but in fact related aspects of these discussions centred around the status of the international in Gramsci's thought: on one hand, there are those who maintain that Gramsci's work was fundamentally located at the level of the state and thus there is a problem with 'internationalising' Gramsci's concepts, particularly hegemony and civil society. On the other hand, there are those who believe Gramsci's point of departure may have been international but his political theory was ultimately 'domesticated' in response to the failures of working class movements in Western Europe to seize power. These interpretations of Gramsci result in similar conclusions, albeit from apparently opposite directions. Both approaches contend that Gramsci's writings are problematic and inadequate with respect to the international and that it is stretching his legacy to apply his conceptions in this sphere.

As we illustrate below, whatever the merits of the specific points produced by the various positions in this debate, the general discussion is hampered by the neglect of Gramsci's consistent focus on the relationship between the domestic ${ }^{2}$ and the international in his analysis and political strategy. Indeed, the debate has most often presupposed a strict disjuncture between the international and the domestic, with critics then faulting Gramsci for not abiding such abstractions. ${ }^{3}$ The quagmire of much of the scholarship concerning 'internationalising Gramsci' is precisely the presumption of a theory of the international counter-posed to an analysis of politics internal to the nation-state (a presupposition to which some of those in the so-called 'neo-Gramscian school' have contributed). ${ }^{4}$ As the textual analysis offered below shows, Gramsci begins analytically from 'global' position focused on politics and political community in which the historical formation of the modern nation-state is theorised. We will show Gramsci's consistent attention to the mutually constitutive relationship between the two, even when the 'national' was his apparent focus of discussion.

To illustrate our contention that the persistent deadlock regarding whether Gramsci's concepts have been or can be 'internationalised' or 'translated' to the international level begins from false premises, our discussion is structured in two broad parts. First, we unpack the foundations of the critiques of 'internationalising Gramsci' from both the perspective that his work begins from the domestic and the

Gramsci's concepts can be 'internationalised'. Gramsci himself uses 'internazionale' often (although with overtones of the Communist International) but he also frequently uses the terms 'mondo' (world) and 'mondiale' (worldwide) which have certain advantages but are mostly translated as 'international'. As we shall demonstrate, Gramsci's consistent attention to international dimensions of analysis allows him to situate domestic examinations in wider contexts without falling into the above issues with the term 'international'.

2 We use the term 'domestic' in reference to phenomena at the 'national level' where using the term 'national' may inaccurately imply a connection to a political strategy of constructing the nation, as we will discuss below.

3 While we do not wish to expand our contention beyond the scope of an article length study, the presumed abstract lines between national and international deriving from mainstream approaches to International Relations can hardly be used to criticise Gramsci unless we are to ignore much of the engagement for which he is famous.

4 Even advocates of the applicability of Gramsci's concepts to contemporary international analysis, often labelled 'neo-Gramscians', describe their method as 'internationalising' or 'translating' Gramsci's concepts his focus on the state to the international level. This arguably stems from Robert Cox's seminal article on developing a Gramscian approach to International Relations, see: Robert Cox, 'Gramsci, Hegemony and International Relations', Millennium, 12:2 (1983), pp. 162-75. 
perspective that it ends there. These arguments stem from debates regarding method and politics in approaching Gramsci's texts: whether they must be characterised as ultimately inconsistent and incoherent due to their form and thus read 'symptomatically' or whether they reveal an abandonment of Marxian theorising. We consider the origins of these positions in the secondary literature and illustrate why we do not think they are convincing when considered against a careful reconstruction and reading of Gramsci's oeuvre. We then provide a philological reading of some of Gramsci's key writings on state development, the national-popular, and the Rotary Club (as an example of an international non-governmental organisation), to illustrate the type of omissions, partial readings, and misunderstandings that have riddled much of the previous literature concerning Gramsci's approach to international and domestic relations.

The intervention offered here is sympathetic to that of Adam Morton, who has also addressed critiques of 'internationalising Gramsci' and investigated the international dimensions of Gramsci's conception of state formation. ${ }^{5}$ Similarly, Bob Jessop has argued that Gramsci "was not a "methodological nationalist" who took the national scale for granted but typically analysed any particular scale in terms of its connections with other scales' ${ }^{6}$ Our goal is to provide further evidence for the discussion and to illuminate potential explanations for the persistence of an inadequate framing of the debate. Through a textual analysis we will show how Gramsci's political thought did not subscribe to the pronounced partition between domestic and international that has largely characterised the social sciences and affected the reception of his work.

This, of course, does not eliminate the distinction between the national and international. To do so, would, among other problems, risk devaluing Gramsci's consistent focus on the state, state-formation and institutions and cultural practices related to nation-building including the shaping of domestic production and markets. Our reading of Gramsci does however undercut the idea that he provides a distinct logic operating ontologically at the international level but not the domestic. Instead, we argue, Gramsci begins analytically from an 'international' context and then makes distinctions based on the complex histories of state-formation in their successes and failures.

\section{'Internationalising' Gramsci?}

Despite significant refutations and critiques, many of the basic arguments of Randall Germain and Michael Kenny's influential 1998 article, 'Engaging Gramsci: Interna-

5 Adam David Morton, 'Historicizing Gramsci: Situating Ideas In and Beyond their Contexts', Review of International Political Economy, 10:1 (February, 2003), pp. 118-46; Adam David Morton, Unraveling Gramsci: Hegemony and Passive Revolution in the Global Political Economy (London: Pluto, 2007); Adam David Morton, 'Waiting for Gramsci: State Formation, Passive Revolution and the International', Millennium: Journal of International Studies, 35:3 (2007), pp. 597-621; Adam David Morton, 'Disputing the Geopolitics of the States System and Global Capitalism', Cambridge Review of International Affairs, 20:4 (2007), pp. 599-617; and Adam David Morton, Revolution and State in Modern Mexico: The Political Economy of Uneven Development (Lanham: Rowman \& Littlefield, 2011).

${ }^{6}$ Bob Jessop, State Power (Cambridge: Polity, 2008), p. 105. In a different way, Ian Bruff has also emphasised the 'simultaneous relatedness and methodological distinctiveness' of the national and international in Gramsci although his purpose is to use the strength of Gramsci's approach to draw out the national distinctiveness of European varieties of capitalism, Ian Bruff, 'European Varieties of Capitalism and the International', European Journal of International Relations, 16:4 (2010), pp. 615-38. 
tional Relations Theory and the New Gramscians', continue to frame the debate. ${ }^{7}$ For example, in 2008 Julian Saurin argued that '[a]lmost a decade ago, Germain and Kenny rather gently argued that "some of the claims that have been advanced by the Italian school look rather tenuous when considered against the backdrop of the principle interpretive debates which Gramsci's works has generated" [sic]. ${ }^{8} \mathrm{He}$ insists that Germain and Kenny's argument has been unfairly discounted or ignored by many neo-Gramsicans and attempts to show further problems in 'internationalising' Gramsci's categories. Saurin captures a widespread perception in his claim that, 'Gramsci himself did not elaborate a distinctive concept of the international and, indeed, the major task that the neo-Gramscians set themselves was precisely to see if a distinctive theorization of the international could be extrapolated from Gramsci's sporadic reflections on the international.'9 Owen Worth similarly contends, 'Gramsci himself focused on a theory of the state, which contained only fleeting references to how this might work at the international level.' ${ }^{10}$ Even in her insightful analysis of Gramsci's conception of the law as useful for theorising international law and global capitalism, Claire Cutler presents a similar notion, 'Gramsci's conceptualisation of hegemony was clearly bound up with the state and civil society and raises the issue of whether hegemony is conceivable outside the state (and civil society) where international anarchy is said to prevail.' ${ }^{11}$ Joseph Femia is perhaps the most blunt in his 2005 argument that, 'Antonio Gramsci had very little to say about international relations ...', based on the assessment that '[i]n Gramsci's usage, hegemony referred to the cultural or spiritual supremacy of a class or group within a particular national entity' and the notion that hegemony could 'penetrate beyond national borders' was

7 Randall D. Germain and Michael Kenny, 'Engaging Gramsci: International Relations Theory and the New Gramscians', Review of International Studies, 24:1 (1998), pp. 3-21. Indeed, a fundamental point of contention is whether there is a coherent 'neo-Gramscian' school of IPE. Those working with Gramsci in IR have tended to resist such a label, Stephen Gill, 'Epistemology, Ontology, and the "Italian School",, in S. Gill (ed.), Gramsci, Historical Materialism and International Relations (Cambridge: Cambridge University Press, 1993), pp. 21-48, while critics such as Germain and Kenny, and others have sought to generalise about such work, see also Alison J. Ayers, 'Introduction', in A. J. Ayers (ed.), Gramsci, Political Economy, and International Relations Theory: Modern Princes and Naked Emperors (New York: Palgrave, 2008), pp. 1-22.

8 Julian Saurin, 'The Formation of Neo-Gramscians in International Relations and International Political Economy', in Alison J. Ayers (ed.), Gramsci, Political Economy, and International Relations Theory: Modern Princes and Naked Emperors (New York: Palgrave, 2008), pp. 23-43, p. 29. Interestingly, though a critic, Saurin recognises the lack of a single 'neo-Gramscian' position and suggests that such critique is more accurately directed at 'neo-Coxians' than 'neo-Gramscians', Saurin, 'The Formation', pp. 23-43.

9 Saurin, 'The Formation', p. 31. We will discuss below how the common invocation of the sporadic nature of Gramsci's writings to render dubious and partial readings of his prison writings has a long history, one that is being undermined by research more directly tied to Gramsci's actual writings.

10 Owen Worth, 'Beyond World Order and Transnational Classes: A (Re)Application of Gramsci in Global Politics', in Mark McNally and John Schwarzmantel (eds), Gramsci and Global Politics (London: Routledge, 2009), p. 9. Worth provides a telling example in that he explicitly departs from the position that Gramsci's concepts 'cannot be transposed to the international/global arena' but abides by the structure of the argument premised on a notion that this requires such a transposition. In a more recent article, Worth does not repeat such a claim about Gramsci but more subtly invokes a similar dynamic whereby the work of the 'neo-Gramscians' scholarship 'moved Gramsci into the realm of the international' even though later he recommends a return to Gramsci's writings for an improved approach to international analysis, Owen Worth, 'Recasting Gramsci in International Politics', Review of International Studies, 37 (2011), pp. 373-92.

11 A. Claire Cutler, Gramsci, Law and the Culture of Global Capitalism, in Andreas Bieler and Adam David Morton (eds), Images of Gramsci (London: Routledge, 2006), pp. 133-48, at p. 142. After this sentence Cutler cites Germain and Kenny (1998), as is the common pattern that we are hoping to change. 
'(somewhat isolated)'. ${ }^{12}$ Nor are such positions unique to the International Relations (IR)/IPE debates concerning Gramsci and the international. For example the political and cultural theorist, Susan Buck-Morss, writes, 'Whereas Gramsci's discussion concerns hegemony within the nation-state (the process whereby a nation assimilates all of society to itself), political hegemony is described today as extending globally.'13

Germain and Kenny's original intervention focused on whether certain of Gramsci's concepts can be 'internationalised' and whether so-called neo-Gramscians have presented a viable interpretation of Gramsci's work. The first of these points that methodologically the case for Gramsci's utility in IR depends on the proposition that his concepts, particularly civil society and hegemony, can be internationalised reflects the persistent concern echoed by later interlocutors as noted above. Germain and Kenny argue that any 'neo-Gramscian' claiming lineage to Gramsci's 'civil society' must be able to refashion his famous equation 'state $=$ political society + civil society' to 'international state $=$ global political society + global civil society'. ${ }^{14}$ As we shall show in detail below, careful attention to Gramsci's writings destabilises such a critique by showing how the 'global' is already present in Gramsci's concepts.

With regard to the second point, Germain and Kenny suggest that there are three sets of issues at stake - 'ontology and epistemology'; 'historicism, structuralism and subjectivity'; and 'meaning, appropriation and the history of ideas' - which neoGramscians ostensibly oversimplify, not recognising Gramsci's own ambiguity in part because they fail to adequately engage the secondary literature on these matters. Adam Morton has taken up Germain and Kenny's use of the 'historicism' trope to organise their critique, noting that beyond a vague call to engage with the literature on the history of ideas, they do not substantially elaborate what historicising a thinker means or involves, and in fact their position seems remarkably similar to that of Robert Cox. ${ }^{15}$ Morton's text provides precisely such an elaboration from a Gramscian perspective by outlining the debates between what he labels 'austere' and absolute historicism.

Another of Germain and Kenny's arguments echoed more recently by Saurin is that Gramsci's method is in fact more problematic than how it has been represented in IR: 'the principal difficulty with the Italian school's reading of Gramsci stems from the assumptions of theoretical coherence and interpretive clarity which they attribute to his work'. ${ }^{16}$ Their contention that Gramsci's writings are ambiguous does not rely on direct textual exegesis, nor do they acknowledge the questions of translation that have affected access to Gramsci's texts and their reception in the Anglophone world. Germain and Kenny indeed go so far as to claim that because there have been different scholarly interpretations of his work, 'it is perhaps more accurate to consider his epistemological and ontological ideas as innovative and

12 Joseph Femia, 'Gramsci, Machiavelli and International Relations', The Political Quarterly, 76:3 (July 2005), pp. 341-9, at pp. 341, 342, 343.

13 Susan Buck-Morss, 'Sovereign Right and the Global Left', Rethinking Marxism, 19:4 (October 2007), pp. 432-51, at p. 440. This contention then leads Buck-Morss to turn to the writings of Carl Schmidt to theorise 'global hegemony'. For further examples of more subtle ways in which this influence has operated see Marcus Green and Peter Ives, 'Review', Rethinking Marxism, 23:2 (April 2011), pp. 28291, esp. pp. 289-90.

14 Germain and Kenny, 'Engaging', p. 17.

15 Morton, 'Historicizing Gramsci'.

16 Germain and Kenny, 'Engaging', p. 9; and Saurin, 'The Formation', pp. 30-1. 
eclectic but ultimately problematic'. ${ }^{17}$ This formulation is untenable - little political theory is not subject to contested interpretations - but it does reflect a certain conventional wisdom about the difficulty of reading Gramsci's prison notebooks due to their unfinished and fragmentary form. For those involved in reading Gramsci's texts in their own right, however, such caveats often seem to be invoked to provide cover for 'instrumental' readings of his work. ${ }^{18}$ Of course, Gramsci himself was the first to be cautious about the provisional nature of his writings, what Edoardo Sanguineti calls a monomania, with reiterated phrases such as 'so to say', 'in some sense', 'in a certain respect', and other caveats. ${ }^{19}$ Gramsci similarly noted the philological complexities of dealing with Marx's unpublished works. ${ }^{20}$ However, unless we are to abandon the notion that there is anything of use in Gramsci's prison writings, the nature of these writings calls for more careful attention to the texts. We follow the general developments of methods in Gramscian scholarship especially in Italy since the publication of the 1975 critical edition and Gianni Francioni's L'Officina Gramsciana. ${ }^{21}$ These developments insist on seeing Gramsci's corpus as a whole, albeit unfinished, research project.

As Adam Morton has observed in the context of discussions regarding 'historicising' Gramsci, disputes about Gramsci and 'the international' are complicated by the related issue of the breadth of interpretations of Gramsci's politics in the secondary literature. ${ }^{22}$ Morton highlights the appropriation of his work by interlocutors that are more influenced by liberal political-theoretical attachments than a commitment to historical materialism (for example, Richard Bellamy). ${ }^{23}$ There has also been a 'post-Marxian' reading of Gramsci in the secondary literature, one that is arguably methodologically predisposed to emphasise the perceived ambiguity of his work in its emphasis on the 'symptomatic reading'. Peter Thomas has traced the origins of some aspects of the diversity of these interpretations using, among other methods of contextualising and historicising, Francioni's analysis of the structure of the prison notebooks. In the process, he convincingly critiques readings of Gramsci's work that see it as non-Marxist or fraught with contradictions. He focuses on arguably two of the most influential interpretations of Gramsci's oeuvre: Louis Althusser's 'symptomatic' approach to reading Gramsci and Perry Anderson's engagement with the perceived 'antinomies' of Gramsci's thought, illustrating how the question of ambiguity itself reflects a deeper methodological-political debate within the secondary

17 Germain and Kenny, 'Engaging', p. 12.

18 See Joseph Buttigieg, 'The Prison Notebooks: Antonio Gramsci's Work in Progress', Rethinking Marxism, 18:1 (2006), pp. 37-42; Peter Thomas, The Gramscian Moment: Philosophy, Hegemony and Marxism (Boston: Brill, 2009), pp. 45-7.

19 Edoardo Sanguineti, 'Gramsci from One Century to Another: An Interview by Giorgio Baratta', in Peter Ives and Rocco Lacorte (eds), Gramsci, Language and Translation (Lanham: Lexington Press, 2010), pp. 101-6, at p. 102-3.

20 Antonio Gramsci, Selections from the Prison Notebooks, Quintin Hoare and Geoffrey Nowell Smith (eds) (London: Lawrence \& Wishart, 1971), p. 384. As we will explain below, to facilitate our philological method, we will follow the standard practice of referencing Gramsci's Prison Notebooks by providing the Notebook number preceded by a Q (for 'Quaderno', Notebook, in Italian), and then a $\S$ prior to the note (or section) number, in this case Q16\$2. This enables the reader to understand where in Gramsci's actual notebooks the text is from as well as locate it in various anthologies and translations. We will follow this with the citation of the translation used.

21 Gianni Francioni, L'Officina Gramsciana: Ipotesi sulla struttura dei 'Quaderni del carcere' (Naples: Bibliopolis, 1984).

22 Morton, 'Historicizing Gramsci', p. 120; Morton, Unravelling Gramsci, pp. 18-24.

23 Morton, 'Historicizing Gramsci,' p. 129; Morton, Unravelling Gramsci, pp. 24-36. 
literature. As Thomas demonstrates, these problematic readings of Gramsci have become widely diffused, establishing almost 'common sense' positions concerning the prison notebooks, as the IR debates about Gramsci and the international seem to illustrate.

Thomas establishes the basis of a critique of the 'post-Marxist' appropriation of Gramsci by analysing the 'Althusser versus Gramsci' moment in Marxist philosophy. Perhaps more significantly for the discussion here, Thomas also shows how Anderson's reading introduces several enduring misconceptions through a flawed strategy of philological reconstruction: ${ }^{24}$

- the notion that Gramsci's discussion of the relationship between the state and civil society is confused and imprecise, owing to the influence of Croce, rather than a Marxian reconstruction of liberal categories, ${ }^{25}$

- the idea that the terrain of hegemony was civil society, not the state, ${ }^{26}$ and associated with that, the widespread idea that Gramsci derived his conception of civil society from Hegel rather than Marx. ${ }^{27}$

Contra Anderson, Thomas illustrates that political and civil society will be misunderstood if they are conceived of as being located literally in bounded or defined spaces. As with Gramsci's important characterisation of the 'integral State', civil society and political society (the State narrowly understood) reflect relations that are functionally (not spatially) constructed in Gramsci's thought. Hegemony traverses them as 'a particular practice of consolidating social forces and condensing them into political power on a mass basis - the mode of production of the modern "political", ${ }^{28}$ Thus reducing civil society, political society, and hegemony to the territorial containment of the nation and then asking if they can be 'internationalised' is to misconstrue Gramsci's approach. Although Anderson's reading has been subject to significant challenge within Gramsci-specific scholarship, outside of this sphere the influence of Anderson's approach has endured unquestioned, particularly among Anglophone Marxists. ${ }^{29}$ Thomas's suggestion that Gramsci remains mysterious to Anglophone audiences because (not in spite) of Anderson's intervention helps explain the enduring impact of Germain and Kenny's critique. ${ }^{30}$

24 As Thomas illustrates, Anderson's project is further complicated by his own appeals to diverse perspectives: 'Although he stressed on numerous occasions that the central terms of his study were dictated by Gramsci's own incomplete conceptual structure (philology seemingly being invoked in the sense of textual limitation), "The Antinomies of Antonio Gramsci" in actual fact proceeded in a more eclectic mode. Kautsky, Lenin, Luxemburg, Trotsky, Bordiga, Althusser, Poulantzas, Miliband and Mandel were all called on different occasions as witnesses to the development of the concept of hegemony and related terms. The analysis of the antinomies contained in Gramsci's own elliptical formulations thus regularly gave way to an excavation of their theoretical and political precedents and contemporary reverberations, before returning with the resources thus gained to continue the task of philological elucidation, strictly understood. In this sense, Anderson's essay reproduced something of the fragmentary structure of the very text that it proposed to analyse: detours via detours, a labyrinth within a labyrinth.' Thomas, The Gramscian Moment, esp. pp. 52-3. See Perry Anderson, 'The Antinomies of Antonio Gramsci', New Left Review, (1976-7), pp. 5-78.

25 Thomas, The Gramscian Moment, especially Chapter 2.

26 Ibid., p. 167.

27 Ibid., pp. 173-4.

28 Ibid., pp. 182-94; see also Jessop, State Power, pp. 112-16; and Morton, Unravelling Gramsci, pp. 8990.

29 Thomas, The Gramscian Moment, pp. 80-3.

30 Ibid., p. 82. 
In sum, beyond the charge that certain categories in Gramsci's thought are exclusively 'national' in orientation, critics argue that neo-Gramscians have failed to appreciate Gramsci's ambiguities and thus the difficulties of making any definitive claims about his ontological, epistemological, and indeed political commitments. Germain and Kenny maintain that neo-Gramscians are blind to the significance of the interpretive debates around Gramsci's work in their failure to adopt a 'symptomatic' reading of Gramsci. Yet appealing to a 'symptomatic' reading in itself reflects a highly contested - and indeed, as Thomas has shown, 'political' - claim about the intelligibility of Gramsci's scholarship, one increasingly under challenge by those engaged in reconstructing Gramsci's prison writings. The debates about the possibility of reconstructing a 'secure' Gramsci are densely articulated to those about Gramsci's specific political commitments - was he a Marxist? - which are echoed in the other half of the debate about 'internationalising' Gramsci's thought, to which we turn now.

\section{Gramsci, the international, and Marxian praxis}

Some critics have suggested that Gramsci's discussion of the national following the defeat of working class movements in the West represents a foreclosure of his engagement with the international. For example, Robbie Shilliam accepts the basic premise that Gramsci's move to the domestic represents a strategic question in Marxian revolutionary praxis. He finds fault, however, in Gramsci's work as a contribution to the Marxian tradition, based on the claim that 'Gramsci prescribed hegemony in comparative terminology, as an inter-national strategy best adapted to the specifics of differential national conditions. ${ }^{31} \mathrm{He}$ continues with the observation,

[Gramsci's] Internationalist perspective deemed it desirable to somehow unify the discrete sets of national revolutions.... In fact, any strategy that rooted these struggles in a non-materially occupied 'international', (specifically Second Internationalism and Trotsky's 'permanent revolution'), was condemned as vacuous, abstract and thus self-defeating. ${ }^{32}$

As Mark McNally has argued, Gramsci's move to considering the 'national-popular' was indeed a praxeological engagement with the defeat of Western European workingclass movements by fascism in the aftermath of the Russian Revolution. ${ }^{33}$ Though this development in his thought did seek to problematise 'his early taste for [a] somewhat abstract and schematic internationalism', it did not imply an abandonment of the international. ${ }^{34}$ Gramsci continued to see capitalism as a global dynamic working within and across state borders and economies as well as the necessity of an international movement to coordinate revolutionary struggles, as evidenced in Gramsci's

31 Robbie Shilliam, 'Hegemony and the Unfashionable Problematic of "Primitive Accumulation", Millennium: Journal of International Studies, 33 (2004), pp. 59-88, at p. 72.

32 Shilliam, 'Hegemony and the Unfashionable Problematic of "Primitive Accumulation",, p. 73. As Thomas cautions, furthermore, 'in reality, despite Gramsci's emotionally charged personal reaction to Trotsky, the terms of their analyses are remarkably similar and complementary', in that the latter analysed state weakness in the East and the former theorised 'the implications for revolutionary strategy of what Trotsky described as the "heaviest reserves" of the bourgeoisie in the West'. Thomas, The Gramscian Moment, pp. 173-4.

33 Mark McNally, 'Gramsci's Internationalism, the National-Popular and the Alternative Globalisation Movement', in Mark McNally and John Schwarzmantel (eds), Gramsci and Global Politics: Hegemony and Resistance (New York: Routledge, 2009), pp. 58-76, at pp. 60-1.

34 McNally, 'Gramsci's Internationalism', pp. 61-4. 
debates with other members of the Partito Comuniste d'Italia (PCd'I) regarding its relationship to Moscow. ${ }^{35}$

Shilliam's conclusions, it should be noted, rely on Anderson's reading of hegemony as well as several problematic moves in his own reading of Gramsci's discussion of the Southern Question. In this element of his argument, Shilliam adopts a narrow 'Russian' conception of hegemony, that is, the revolutionary political alliance of the working classes and the peasantry, in so doing denying Gramsci's original contribution to the concept, which was indeed much broader as it elaborated the concept for Western European parliamentary democracies. ${ }^{36}$ Similarly, his claim that Gramsci's understanding of the Southern Question denied the peasantry any political agency is unsupported by a close reading in which Gramsci criticises the Socialist Party (with which the PCd'I would break) precisely for racialised insensitivity to Southerners and a failure to develop genuine solidarity. ${ }^{37}$ Shilliam's overall conclusions, that Gramsci's analysis of the differences between East and West lacked any capacity to analyse the relationship between the two - that his analysis of the uneven development of capitalism was comparative rather than constitutive - equally misunderstands Gramsci's discussion of the material dimension of uneven development between North and South within the Southern Question. ${ }^{38}$

Others have taken this criticism even further to suggest that in the turn towards theorising the national, Gramsci abandoned both the international and Marxism. Joseph Femia argues that those who suggest Gramsci's concept of civil society and hegemony can be internationalised (he focuses on Robert Cox in this regard), rely on a misinterpretation of Gramsci's reading of Machiavelli. Given Femia's stature as a longstanding authority on Gramsci's political theory, whose work is appealed to by both the Germain and Kenny and Shilliam's schools of critique, it is worth considering this line of reasoning in some detail. Femia suggests that although Gramsci 'never formally abandoned his Marxist vision of a perfect world, it is hard to escape the conclusion that he had - by the 1930s - transferred his allegiance to a more Machiavellian view of human life, one where force, hierarchy (and hence conflict) are inevitable'. ${ }^{39}$ There is more textual support, however, for the view that Gramsci drew on Machiavelli's work in the service of a Marxian project, not as an alternative to it. ${ }^{40}$ Gramsci's substantial passage devoted to 'Machiavelli and Marx'

35 McNally, 'Gramsci's Internationalism', pp. 64-5, see also Emanuele Saccerelli, Gramsci and Trotsky in the Shadow of Stalinism: The Political Theory and Practice of Opposition (New York: Routledge, 2008).

36 See Derek Boothman, 'The Sources for Gramsci's Concept of Hegemony', Rethinking Marxism, 20:2 (2008), pp. 201-15.

37 Antonio Gramsci, Selections from the Political Writings 1921-1926 (London: Lawrence and Wishart, 1978), pp. 444-5.

38 Gramsci, Selections from Political Writings, pp. 457-8. See also Frank Rosengarten, 'The Contemporary Relevance of Gramsci's Views on Italy's "Southern Question", in Joseph Francese (ed.), Perspectives on Gramsci: Politics, Culture and Social Theory (London: Routledge, 2009), pp. 134-44; Morton, 'Disputing the Geopolitics'; Morton, Unravelling Gramsci, pp. 137-70. Perhaps not surprisingly, Shilliam cites Anderson to support his claim that Gramsci's analysis was too confused to provide insight into the material logic of uneven development. Shilliam, 'Hegemony'.

39 Femia, 'Gramsci', p. 347.

40 That Saurin relies on Femia to such an extent in a polemic that chastises 'neo-Gramscians' for not reading Gramsci as a Marxist is particularly bewildering. As noted above, in our view, many of the social sciences - including the secondary literature relied upon by favourably cited critics such as Germain and Kenny - have been guilty of reading Gramsci in a non-Marxian way: this is not limited to 'neoGramscian IR', nor indeed does Saurin make a case vis-à-vis 'neo-Gramscian IR' beyond echoing Germain and Kenny's criticism that Robert Cox in particular was influenced by a number of nonMarxian thinkers in his reading of Gramsci. 
(Q13\$20) opens with a reiterating the Marxian orientation of the reading that follows and critiques the received wisdom regarding Machiavelli. Gramsci argues that The Prince was not in fact designed to advise elites but to demystify power for " "those who are not in the know"... the revolutionary class of the time, the Italian "people", ${ }^{41}$ Indeed, far from adopting a 'Machiavellian view of human life' contra a Marxian one, Gramsci begins this section with the observation that: 'the basic innovation introduced by the philosophy of praxis into the science of politics and of history is the demonstration that there is no abstract "human nature" "but only that established by 'historically determined social relations'. ${ }^{42}$

Of particular interest to IR scholars may be Femia's claims that the Machiavellian influence makes Gramsci a realist in at least three respects. First, he argues that this realist influence can be seen in Gramsci's critique of 'universal' moral concepts. Yet, Marxists in general reject the universalist claims of class-specific, bourgeois ethics: this aspect of Gramsci's work does not per se support the contention that Gramsci's engagement with Machivelli rendered him a realist. Second, Femia claims that the cultural emphasis of Gramsci's work pushed him towards a 'particularist or communitarian conception of the human personality. From here it is but a short step to the conventionalist realist assumption that nation-states are natural and "ontologically primitive" units of the international system. ${ }^{\text {"3 }}$ As the discussion below will demonstrate, there is no support for such a 'short step' in Gramsci's work, quite the contrary. Finally, Femia argues that Gramsci absorbed from Machiavelli the position that 'the flaws in human nature make conflict and hierarchy an inescapable reality', based on the assessment that his discussion of the relationship between leaders and led was too ambiguous to sustain the position that the intention of his political theory was to transcend this division. ${ }^{44} \mathrm{He}$ appeals to two elements of the Prison Notebooks: one in which Gramsci observes that even socially homogeneous groups have leaders and a second in which he considers the possibility of the "withering away" of the "coercive element of the State". ${ }^{45}$ Femia asserts: "Surprisingly for a Marxist for his time, Gramsci expresses scepticism about the viability of this scenario, even dismissing it as "pure utopia", since it is based on the unlikely premise "that all men are really equal and hence equally rational and moral, i.e., capable of accepting the law spontaneously, freely, and not through coercion". ' 46 However, this reading misunderstands the logic of the passage from which the quote is taken, in which Gramsci re-reads the liberal conventional wisdom of the state through a Marxian lens. This point is flagged at the outset, where he explicitly defends the left from bourgeois critics on charge of utopianism - 'Clearly in this [that economic equality is a requirement for genuine political equality] the utopians were not utopians, but concrete political scientists and consistent critics.' ${ }^{\prime 7}$ It is in this spirit that Gramsci's use of the term 'utopian' should be read. The 'pure utopia' of the later passage cited by Femia, refers to the liberal premise that people accept the law spontaneously, outside of the context of a specific set of social relations. This discussion in

\footnotetext{
41 Q13\$20, Gramsci, Selections, p. 135.

42 Q13\$20, Gramsci, Selections, p. 133.

43 Joseph Femia, 'Gramsci, Machiavelli and International Relations', Political Quarterly, 76 (2005), pp. 341-9, at pp. 346-7.

44 Femia, 'Gramsci', p. 345.

45 Q15\$4, Gramsci, Selections, pp. 144-5; Femia, 'Gramsci', p. 347.

46 Femia, 'Gramsci', p. 347.

47 Q6\$12, Gramsci, Selections, p. 258.
} 
fact concludes with a comparison of the Marxian withering away of the state with the liberal 'nightwatchman' state: the latter, Gramsci notes, having been appropriated from socialists in the first place. ${ }^{48} \mathrm{He}$ concludes in a way that underscores that the overall theme of the passage is one of challenging liberal conventional wisdom in the defence of a Marxian politics: 'Nor can this [socialist conception of the withering away of the state] conjure up the idea of a new "liberalism", even though the beginning of an era of organic liberty be imminent.' 49

In sum, close readings of Gramsci's discussion of the Southern Question, leadership, and the state do not support the contention that he abandoned the international in favour of the domestic, nor that he abandoned Marxism more generally. The positions that he did so, as with controversies regarding whether the prison notebooks require a 'symptomatic' reading, lie behind the charges that Gramsci's work cannot be understood as involving an account of the international due to methodological and political concerns. As the discussion above illustrates, Gramsci should not be dismissed as a theorist of the international on such grounds. Yet the question remains of whether his work, even read as involving a coherent, stable logic and maintaining a Marxian commitment to international political projects, might nevertheless involve categories constructed around the 'national' in a way that forecloses a theorisation of the 'international'. As we will show in the discussion below, those categories of Gramsci's political theory most often understood as indicating his national focus such as the state, the national-popular, and civil society - in fact consistently illustrate the interpenetration of 'national' and 'international' politics and contexts.

\section{The formation of the nation and the modern state in Italy}

Undoubtedly, Gramsci was very concerned with Italy and, thus, put his analysis of the Italian nation front and centre in his research project. When abstracted, this seems to have led many scholars to assume that Gramsci placed analytic priority on the national level of analysis. Especially if one is reading the English-language anthologies rather than the Italian critical edition, ${ }^{50}$ his 'international' concern and analysis may seem less obvious. But it is only a very partial reading of Gramsci that could lead so many to accept Germain and Kenny's contention of a 'paradox that Gramsci, above all a theorist who grappled with the discourses and realities of "statism" in the early twentieth century, is now being used to theorize not only the existence of a global civil society disembedded from the nation-state, but also a form of hegemony reliant on transnational social forces'. ${ }^{51}$ A closer reading of Gramsci shows clearly that his analysis of 'statism' in the early twentieth century was premised

48 Q6\$88, Gramsci, Selections, p. 263.

49 Q6\$88, Gramsci, Selections, p. 263.

50 Antonio Gramsci, Quaderni del Carcere, 4 volumes, Valentino Gerratana (ed.) (Turin: Einaudi, 1975). The English translation of this critical edition is still under way; the first three volumes of the five volume work have been published by Columbia University Press, edited and translated by Joseph Buttigieg. However, when Germain and Kenny were writing their seminal intervention, only the first two volumes comprising Notebooks 1-5 were available in English (French, Spanish, German, and Portuguese translations have been published). Thus, many of these debates have been heavily influenced by the partial English anthologies of Gramsci's writings especially Gramsci, Selections.

51 Germain and Kenny, 'Engaging Gramsci', p. 4; Saurin, 'The Formation', pp. 33-4; Worth, 'Beyond', p. 21. 
on, and embedded in, an analysis of the international. As argued below, many of his analyses of key institutions of civil society, for instance the Roman Catholic Church and the Rotary Club, are not only transnational in nature, but his analysis of them involves distinguishing and relating their international and diverse manifestations. Germain and Kenny, Saurin and Femia accuse neo-Gramscians of 'decontextualising' Gramsci's work; 52 here we recontextualise his writings by paying close attention to the prison notebooks, in their note-like form, including relying not only on English translations but the Italian critical edition of 1975. In other words, we pursue Germain and Kenny's suggestion of paying greater heed to the interpretations of Gramsci's texts. ${ }^{53}$

We will follow the philological procedure of locating Gramsci's discussion within his own research process. The longest and most substantial discussion of state formation in the English language anthology, Selections from the Prison Notebooks (on which Germain and Kenny rely), is a note entitled, 'The Problem of Political Leadership in the Formation and Development of the Nation and the Modern State in Italy'. ${ }^{54}$ This is a translation of part of Notebook 19, note 24 (Q19\$24). As was Gramsci's common practice, he based this note on an earlier draft, in this case from Q1§44, which he then crossed out. Valentino Gerratana, the editor of the Italian critical edition, labels such initial drafts A-texts, and the revised versions C-texts, with B-texts being those notes that only have one version. ${ }^{55}$ Together with the prior note (Q1§43), these drafts concerning state-formation constitute Gramsci's first real sustained analysis in the prison notebooks that ranges for more than a couple of pages. It is the first time Gramsci mentions 'hegemony' as well as 'passive revolution'. It is a prime example of Joseph Buttigeig's observation that Gramsci's first notebook raises many ideas that will constitute Gramsci's major themes for the entire corpus. ${ }^{56}$

Gramsci's analysis of the development of the nation and the modern state (both the A- and C-texts, Q1\$44 and Q19\$24) focuses on Italy and the major political players and movements of the Risorgimento, that is, domestic actors, the Moderate Party and the Action Party. Yet one of his main criticisms of the Action Party is that it 'confused the cultural unity which existed in the peninsula - confined, however, to a very thin stratum of the population, and polluted by the Vatican's cosmopolitanism with the political and territorial unity of the great popular masses, who were foreign to that cultural tradition and who, even supposing that they knew of its existence, couldn't care less about it'. ${ }^{57}$ Thus, even within texts explicitly focused on the Italian nation-state, Gramsci analyses the uneven formation of the nation and the non-convergence of cultural, political, and territorial aspects of it. What is obvious taking into account more of his writings is that the 'Italian nation', or any conception of the 'nation' is never a given, but always placed in what could be called the 'international' or larger-than-national framework. As in the quote above, he continually

52 Germain and Kenny, 'Engaging', for example, pp. 4-9; Saurin, 'The Formation', pp. 26-33; Femia, 'Gramsci', pp. 342-5.

53 Germain and Kenny, 'Engaging', pp. 4, 7-8, 13, 20.

54 Gramsci, Selections, p. 55.

55 See Valentino Gerratana, 'Prefazione', in Gramsci, Quaderni, pp. xxxvi-xxxvii or Joseph Buttigieg, 'Preface', in Antonio Gramsci, Prison Notebooks, Volume 1, Joseph Buttigieg (ed.) (New York: Columbia University Press, 1991), pp. xvi-xviii.

56 Joseph Buttigieg, 'Introduction', in Gramsci, Prison Notebooks, Volume 1, p. 25.

57 Q19\$24, Gramsci, Selections, p. 63; Gramsci, Quaderni, p. 2014. 
challenges any conception of a national essence, as if there is some sort of teleology of the proto-nation to develop into the nation. Quite the contrary, his consistent point is that the 'nation' is a specifically political project, within a larger terrain. ${ }^{58}$ At times Gramsci is critical of the specifics of certain 'nation-building' efforts precisely due to their non-popular and exclusionary policies. Elsewhere he is also critical of the absence of attempts of progressive nation-building (for example, Q25\$5, Q19\$24). ${ }^{59}$ The point of his analysis is to show where this project is carried out in favour of a historical bloc of a minority of dominant social groups fostering exploitation and oppression, and when it holds possibilities for a more progressive movement capable of challenging such exploitation and oppression. Thus to argue, as Germain and Kenny do, that 'The innovative contribution of the Italian school [neoGramscian] lies in considering civil society at the international or global level ...'60 requires ignoring or misunderstanding Gramsci's analysis of Italian nation-state formation itself. ${ }^{61} \mathrm{We}$ will return to the question of civil society below.

To give another example of how Gramsci does not begin with a domestic focus to the exclusion of an international one, we note the oft quoted passage from Q10\$44 where Gramsci writes, 'Every relationship of "hegemony" is necessarily an educational relationship ...'. The less often quoted conclusion to that sentence is, '... and occurs not only within a nation, between the various forces of which the nation is composed, but in the international and world-wide field, between complexes of national and continental civilisations' ${ }^{62}$ Perhaps a reader could force an interpretation whereby this educational relationship of hegemony happens first at the national or domestic level and that he is positing a simplistic notion that it then occurs between nations, where nations are the focus and the building blocks and not the 'root' of hegemony, to use the idea of Saurin to be discussed in more detail below. But the note is a discussion of 'Language, Languages and Common Sense', in which his main point is that '[c]ulture in its various degrees unifies a majority or minority of individuals in numerous strata, more or less in expressive contact, and that understand each other to diverse degrees etc.' ${ }^{63}$ Elsewhere Gramsci is fully consistent in noting that cosmopolitan culture also unifies individuals (although of different socioeconomic characters) but for different purposes and effects. ${ }^{64}$ Moreover, one of his main arguments is that in Italy, the fragmented subaltern groups do not understand each others' modes of expression, nor that of the elites. ${ }^{65}$ This is why Gramsci devotes such attention towards the cosmopolitanism of Italian intellectuals.

Gramsci explicitly exposes the shortcomings of how others have understood the Italian Risorgimento as the formation of an Italian nation-state. In Notebook 6,

58 Q25§5, Q25§2, Q19\$24, Q19§28, Q19 §26, Gramsci, Selections, pp. 52-102.

59 Gramsci, Selections, pp. 53, 58-64.

60 Germain and Kenny, 'Engaging', p. 7, emphasis added.

61 If Germain and Kenny are arguing that this neo-Gramscian innovation is a new way of considering civil society at the global level that differs from the status of the international in Gramsci's analysis that would be another story. But they are not making such an argument: they contend that Gramsci's conception of civil society is confined to the domestic level. Germain and Kenny, 'Engaging', pp. 3-21.

62 Gramsci, Selections, p. 350.

63 Q10\$44, Gramsci, Selections, p. 349.

64 For example, Q10II§61, Gramsci, Selections, pp. 117-8; and Q29§3, Antonio Gramsci, Selections from Cultural Writings, David Forgacs and Geoffrey Nowell-Smith (eds) (Cambridge, Mass.: Harvard University Press, 1985), p. 183.

65 See Marcus Green and Peter Ives, 'Subalternity and Language: Overcoming the Fragmentation of Common Sense', Historical Materialism, 17 (2009), pp. 3-30. 
he distinguishes "those who want to uphold the autonomous origin of the Italian national movement and who go so far as to maintain that the French Revolution adulterated and side tracked the Italian tradition ... [from] those who assert that the Italian national movement is heavily indebted to the French Revolution and its wars'. ${ }^{66}$ We could roughly equate the latter with cosmopolitan presumptions commonly made by liberalism and the former with more republican traditions highlighting the particular and local. Gramsci rejects both positions and is especially concerned to analyse how such 'ideologies' that have helped reinforce the belief that 'what exists today has always existed and that Italy has always existed as a unified nation but was suffocated by foreign power, etc.'. Gramsci observes 'the consciousness of "cultural unity", which has existed among Italian intellectuals since at least 1200 , that is, since the beginning of the development of a standardized literary language (Dante's illustrious vulgar tongue)' [emphasis added]. Yet, he insists that 'This element, however, does not have a direct effect on historical events'. The position that has been more influential, according to Gramsci, focused on the need for independence of the Italian peninsula from foreign influence. His central point is that both of these perspectives 'pertain to small minorities of great intellectuals, and they have never manifested themselves in an expression of a widespread and solid unitary national consciousness' ${ }^{67}$ In other words, his project is to theorise a more adequate explanation of Italian nation-state formation from the perspective of an international analysis. ${ }^{68}$

When Gramsci comes to list the conditions necessarily to explain national unity the very first one is 'the existence of an international balance of powers that would constitute the premise of Italian unification' and locates it after 1748 with the collapse of French hegemony and exclusion of Spanish-Austrian hegemony. ${ }^{69}$ As will be discussed below, Gramsci addresses the key role of the Roman Catholic Church (an international institution, ideology, and culture), and then moves to domestic, national considerations (note the order from international to national). To reiterate that he never remains solely focused on national phenomena in exclusion from the international, Gramsci includes the observation (anticipating the trajectory of European politics after WWII) that, '[t]here is today a European cultural consciousness, and there exists a long list of public statements by intellectuals and politicians who maintain that a European union is necessary. It is fair to say that the course of history is heading toward this union and that there are many material forces that will only be able to develop within this union. ${ }^{70}$

Gramsci insists on paying attention to the economic context: '[a]ll these questions about origins [of the Italian nation-state] stem from the fact that the Italian economy was very weak and capitalism was just emerging. .. ${ }^{71} \mathrm{He}$ rejects the suggestion that once the fetters to free market forces are removed, Italy will achieve independence. Gramsci then comes to the reverse of the position attributed to him by Germain and Kenny, when they insist, '[y]et it is not at all clear what meaning if any Gramsci

66 Q6\$78, Antonio Gramsci, Prison Notebooks, Volume 3, Joseph Buttigieg (ed.) (New York: Columbia University Press, 2007), p. 58.

67 Q6\$78, Gramsci, Prison Notebooks, Volume 3, p. 58.

${ }^{68}$ Morton, 'Waiting for Gramsci'.

${ }^{69}$ It is worth noting that this is one of many examples of Gramsci's use of 'hegemony' in the international domain, which according to Germain and Kenny he does not do.

70 Q6\$78, Gramsci, Prison Notebooks, Volume 3, pp. 60-1.

71 Q6\$78, Gramsci, Prison Notebooks, Volume 3, p. 60. 
would attribute to the domain of civil society if it could be neither represented through the imagery of the nation nor considered in relation to the state. ${ }^{\prime 2}$ Gramsci makes it evident that he is discussing how the nation and the state are being represented and indeed constituted through the imagery and the institutions of civil society, not the other way around. To read Gramsci as Germain and Kenny do would imply that Gramsci thinks such institutions as the Roman Catholic Church and the Rotary Club, which we will discuss below, are purely national organisations bounded by the nation-state. ${ }^{73}$ This is clearly not the case.

To give another example of Gramsci's approach to the international, we can turn to an additional frequently quoted passage. In discussing the 'educative and formative role of the State', specifically in terms of 'collective man' [sic], Gramsci is quite clear about distinguishing and relating national and international levels of analysis, and the general point is that it is the latter that precedes the former (not vice versa) ${ }^{74}$ $\mathrm{He}$ poses many general questions concerning the 'educative and formative role of the State' including morality, how the law and 'freedom' function specifically in 'incorporating' each individual into the 'collective man' the conclusion of which, for Gramsci, is that 'the value of ideologies must also be studied in a treatise of political science'. ${ }^{75}$ It is within this discussion that Gramsci notes that after 1870,

with the colonial expansion of Europe, all these elements change [the rudimentary State apparatus, civil society, military forces, national armed services, etc. ..]: the internal and international organisational relations of the State become more complex and massive, and the Forty-Eightist formula of the 'Permanent Revolution' is expanded and transcended in political science by the formula of 'civil hegemony'. ${ }^{76}$

Thus, the State itself is seen as being constituted both by 'internal' and 'international organisational relations'. Moreover, Gramsci argues that the theory of 'Permanent Revolution' - already a theory of International Relations - is transcended by 'civil hegemony'. If Gramsci had intended this to mean a shift from an international to a national analysis, he would not have placed such emphasis on the 'international organisational relations' and thus by 'civil hegemony' as an expansion must include these international dimensions of power. These passages challenge Saurin's framing of the question of hegemony and the international. He contends that Gramsci's 'ambiguous' considerations of hegemony 'internationally' must fall into one of two options whereby 'hegemony is little more than the aggregation of national expressions of hegemony ...' or it 'is not rooted in nationally constituted expressions', ${ }^{77}$ which he proposes overcoming through what he calls 'dialectical abstraction'. However, because Gramsci never posits such static and simplistic oppositions between the national and international, Saurin has set up a false obstacle to overcome.

In Notebook 14, specifically note 68, Gramsci addresses these issues head on. In many ways it was a wise editorial decision in the English edition of the Prison Notebooks to place this note, Q14§68, just prior to the one previously discussed,

72 Germain and Kenny, 'Engaging', p. 14.

73 See Germain and Kenny, 'Engaging', p. 14.

74 Q13\$7, Gramsci, Selections, p. 242.

75 Q13\$7, Gramsci, Selections, p. 243.

76 Q13\$7, Gramsci, Selections, p. 243. Thus, to be clear, contra those who would understand 'civil' as necessarily a 'national' category in Gramsci's thought and in sympathy with Thomas, discussed above, we argue that this discussion in Gramsci's work illustrates that he understood it as a relational category that could operate beyond the 'nation' or 'State' classically understood.

77 Saurin, 'The Formation', p. 38. 
Q13\$7. ${ }^{78}$ However, to reach a more nuanced understanding of Gramsci's view we should be aware that the notes were separated and in the reverse order than they appear in the English anthology. Note Q13§7 comes after a discussion of Mosca (Q13§6) and Machiavelli (Q13§5). Thus, the reference to 'Permanent Revolution' does not have the same resonance as in the English Selections from the Prison Notebooks, created by Q14\$68's explicit discussion of Stalin, Lenin, and Marx's different formulations of how 'the international situation should be considered in its national aspect'. ${ }^{79}$ Here he notes specifically that '[a] class that is international in character has ... to "nationalise" itself in a certain sense. 80 Thus, it is difficult to see in what sense critics of the neo-Gramscians claim that Gramsci himself did not place his historical materialist analysis within an international theory of nation and state formation.

Our point here complements and extends one of the arguments made by Adam Morton in response to Germain and Kenny. In identifying a method of 'historical analogy' in Gramsci's work to extrapolate a discussion of modern state formation in the context of the notion of passive revolution, Morton suggests '[i]n essence, the "national" is theorised as a point of arrival within "the international" conditioning of capitalist expansion.' As a result, 'variations in the actual process whereby the same historical development [that is, passive revolution] manifests itself in different countries have to be related not only to the differing combinations of internal relations within the different nations, but also to the differing international relations' ${ }^{81}$ In this account, contra critics such as Shilliam and Femia, the national does not replace the international, but both 'levels' remain active sites of political-economic contestation.

\section{National-popular}

Perhaps an even greater omission of Gramsci's actual arguments is seen when the critics of neo-Gramscianism interpret Gramsci's use of the concept of 'nationalpopular' as evidence of his narrow focus on the Italian nation-state. ${ }^{82}$ Gramsci's actual use of the concept is more subtle and complex, and once again it resembles the opposite of what has been claimed. First mentioned in Notebook 3, Gramsci uses the concept of the 'national-popular' [popolo-nazione] especially to develop his analysis of the lack of connection and interaction in Italy between the elite intellectuals and the popular masses. It thus becomes a major theme connected to his analysis of the Catholic Church and its impact on Italy, which, as we shall see, has everything to do with his analysis of the civil society/state relationship at the heart of the so-called problem of using Gramsci in contemporary International Relations.

One of Gramsci's most pertinent elaborations of his conception of 'nationalpopular' is in the 'special notebook', Notebook 21 concerning popular literature, in note 5, explicitly entitled, 'Concept of "National-Popular"', Here he states:

\footnotetext{
78 Gramsci, Selections, pp. 240-3.

79 Gramsci, Selections, p. 240.

80 Q14§68, Gramsci, Selections, p. 241.

81 Morton, 'Waiting for Gramsci', p. 615. Morton has expanded this point in reference to his analysis of contemporary Mexico, see Morton, Revolution and State, for example, pp. 59-60 and 99-131.

82 See, for example, Germain and Kenny, 'Engaging', p. 14, p. 17.
} 
One should note that in many languages, 'national' and 'popular' are either synonymous or nearly so (they are in Russian, in German, where völkisch has an even more intimate meaning of race, and in Slavonic languages in general; in France the meaning of 'national' already includes a more politically elaborated notion of 'popular' because it is related to the concept of 'sovereignty': national sovereignty and popular sovereignty have, or had, the same value). In Italy the term 'national' has an ideologically very restricted meaning, and does not in any case coincide with 'popular' because in Italy the intellectuals are distant from the people, i.e. from the 'nation'. 83

Far from beginning with the notion of the nation and any necessary or primordial link between the national and the popular, Gramsci is problematising it, tracing out its connections to social relations and class interaction. His use of 'national-popular' to analyse the Italian situation is an investigation of its irony or problematic nature as a linking of incompatible terms. It is only his comparative, 'international' analysis that draws on the coincidence of the 'national' with the 'popular'. In her entry for 'national-popular' in the Dizionario Gramsciano, Lea Durante emphasises that Gramsci's starting point is the absence of the national in Italy, as manifested by the lack of an Italian popular literature as compared to France and other countries. This absence, for Gramsci, is not a question of backwardness or an obstacle to a teleological formation that is destined to, or should, occur. Rather Gramsci's interest in this absence is as a symptom of the gap between the masses and the intellectuals which thus fails to constitute a 'people'. Gramsci's fuller analysis of the lack of a nationalpopular is quite explicit here especially with regard to language, ' $[t]$ he question of the language posed by Manzoni also reflects this problem, that the moral and intellectual unity of the nation and the state, sought in a unity of the language.' The analytic work to which Gramsci puts the concept of the 'national-popular' is precisely how it is that a diverse collection of people, stretched over a relatively large territory, with different histories and especially differing economic interests are or are not yoked with an 'archaeological and moth-eaten conception of the country's interests'. ${ }^{84}$

In sum, the entire question of whether or not key concepts like hegemony or civil society can be 'internationalised' begins from premises at odds with Gramsci's actual writings, which show they are in fact already constituted as international phenomena in his work. This indeed should have seemed obvious from what Germain and Kenny actually note in their critique; 'such national character [of civil society], for example, is reflected in Gramsci's consideration of the origin of what he terms 'common sense', and especially its links to religion. ${ }^{85}$ Of course, Gramsci understood religion as an international phenomenon and analysed how 'common sense' could be national or international, as he did many other aspects of civil society, to which the next section turns.

\section{Civil society, class, and cosmopolitanism}

In addition to a one-sided reading of Gramsci's focus on nation-state formation as if it excludes international analysis, the notion that 'civil society' must be conceived in

83 Q21§5, Gramsci, Selections from Cultural Writings, p. 208.

84 Q21§5, Gramsci, Selections from Cultural Writings, pp. 208-9.

85 Germain and Kenny, 'Engaging', p. 14, emphasis added. In their discussion of civil society Germain and Kenny cite a total of eight pages from the prison notebooks - pages 12, 419-25 (421), 263 - and an article by Anne Showstack Sassoon, 'Family, Civil Society, and the State: The Actuality of Gramsci's Notion of "Societa Civile"', Dialektik, 3 (1995), pp. 67-82. 
a narrow, nationally-contained sense, as explicitly argued by Germain and Kenny and Saurin, ${ }^{86}$ also forecloses attention to Gramsci's ongoing concern with cosmopolitanism. Gramsci discusses the distinctions between internationalism and cosmopolitanism as early as 1918 in his journalism. ${ }^{87}$ In this analysis, internationalism is an approach that encompasses internationally linked production and exchange, while cosmopolitanism is cultural and class-based, the narrow perspective of a small elite, 'that of the bourgeois, who travels for business or pleasure'. ${ }^{88}$ Indeed, as Morton notes, Gramsci wrote in his pre-prison writings: 'on the economic level, the bourgeois class is international: it must necessarily wield across national differences', to result in a class doctrine that is 'liberalism in politics and free trade in economics' ${ }^{89}$

In prison, Gramsci develops this critique of cosmopolitanism with greater nuance and a change in the role of the state and nationalism. ${ }^{90}$ As Timothy Brennan has argued, it was the centrality of the Italian intellectuals to European cosmopolitanism that, coupled with social heteronomy of Italy, created the terrain upon which nineteenth-century nationalists found themselves. ${ }^{91}$ The intellectual project of constructing a new 'national consciousness' concerned itself with the 'continuity of the Italian tradition since the times of ancient Rome' and began to address the 'problem of this interruption' especially of the 'hegemony of Germanic law' over Latin law (during which time the language Middle Latin is virtually the only remaining link between the old [Roman legacy] and the new'. ${ }^{92}$ Despite this apparent break, the Roman Empire's cosmopolitan legacy would have lasting effects: as the centre of the Empire, '... Rome and its territory, becomes the melting pot of the cultured classes from all the imperial territories. The ruling personnel becomes increasingly imperial and decreasingly Latin; it becomes cosmopolitan: even the emperors are not Latin, etc. ${ }^{93}$ In the Renaissance this non-national, cosmopolitan role of Italian intellectuals was repeated, adding to the picture of the obstacles facing nineteenthcentury nationalism in Italy (Q3\$87). In other words, Gramsci adds to the common focus on how the Pope's location in Rome complicates Italian nation-state formation the broader (more international) perspective of Catholic intellectual formation being cosmopolitan rather than national. This is another example of how he theorises specific distinctions and tensions between the domestic and the international levels of activity, without defining them in simplistic opposition.

Gramsci ties these issues into his concern with the deep chasm in Italy between the masses and the cultural elite and intellectuals that we have already discussed. By Notebook 10, Gramsci relates this longer historical reach back to the Roman Empire to the specific context of modern Italy from the French Revolution through the

86 Germain and Kenny, 'Engaging Gramsci', pp. 7, 14, 15; Saurin, 'The Formation', pp. 34-5.

87 See Peter Ives, 'Cosmopolitanism and Global English: Language Politics in Globalisation Debates', Political Studies, 58 (2010), pp. 516-35, at pp. 523-4.

${ }^{88}$ Gramsci, Selections from Cultural Writings, p. 27.

89 Antonio Gramsci, 'The Social Function of the National Party' (1918) as quoted and discussed in Morton, 'Waiting for Gramsci', pp. 616-7.

90 See Ives, 'Cosmopolitanism', pp. 525-27.

91 Timothy Brennan, Wars of Position: The Cultural Politics of Left and Right (New York: Columbia University Press, 2006), pp. 214-15. At the same time Brennan eelebrates Perry Anderson's reading of Gramsci that we have criticised above, see p. 241.

92 Q3\$87, Antonio Gramsci, Prison Notebooks, Volume 2, Joseph Buttigieg, ed. (New York: Columbia University Press, 1996), pp. 86-7.

93 Q3§88, Gramsci, Prison Notebooks, Volume 2, p. 90. 
Risorgimento concluding that 'the basis for Italian national culture' was not in Italy but

this 'Italian' culture is the continuation of the mediaeval cosmopolitanism linked to the tradition of the Empire and the Church. Universal concepts with 'geographical' seats in Italy. The Italian intellectuals were functionally a cosmopolitan cultural concentration; they absorbed and developed theoretically the reflections of the most solid and indigenous contemporary Italian life. This function can be seen in Machiavelli too, though Machiavelli attempted to turn it to national ends (without success and without any applicable result). The Prince, in fact, was a development of Spanish, French and English experience during the travail of national unification. ${ }^{94}$

Gramsci concludes by criticising current nationalists for basing themselves on 'anachronistic experience rather than immediate national needs, it is they who are the Jacobins in the pejorative sense' 95

Gramsci is interested in the possibility of an alternative, progressive Italiannation building in overcoming this cosmopolitanism. Yet this should not be conflated with Gramsci being primarily a theorist of politics at the nation-state level. Gramsci pays careful attention to the Church as an international institution with various and competing forces within it, a key producer of intellectuals as well as a complex field of cultural and educational production with a heavy influence on what becomes 'common sense'. In short, Gramsci's analysis of the Roman Catholic Church challenges many of the contentions made by the critics of the neo-Gramscians given its historical and continued role as a key international institution. Rather than going further with this example, however, we will consider a very different, more contained, example of the Rotary Club. This shows how Gramsci analyses organisations in both their 'international' and national manifestations. Key here is how he theorises the importance of the national differentiation, as opposed to merely dividing phenomena into different levels of analysis. We take this as a particularly pertinent example of a non-governmental organisation, typical of contemporary conceptions of civil society.

In his first notebook, a few notes after his discussion of the formation of the Italian nation-state, discussed above, Gramsci raises a crucial question, how to analyse clerics as a type of intellectual, and in so doing he first mentions the Rotary Club (Q1§51). While never a major theme, Gramsci discusses the Rotary Club again in Notebooks 4, 5 (with two notes actually entitled Rotary Club, §2, §61), 12, 14, and 15 , as well as the crucial 'special notebook' on Machiavelli, Notebook 13, and then in three different notes in the other famous notebook, 22 on Americanism and Fordism $(\S 1, \S 2$, and $\S 15)$. On first read, these earlier notes may appear as not much more than extracted passages from publications such as La Civiltà Cattolica, Corriere della Sera, and The Rotary Wheel. But as we shall see, looking at them together with the conclusions he draws and repeats in later notebooks, if rather formulaically and cryptically, Gramsci is clearly presenting the Rotary Club as an international institution that requires inquiry by Marxists. He is providing a specific analysis of the ideological functions of it that are not found in any of the sources from which these earlier notes draw. According to Femia, Gramsci identified civil society with '... the institutions and technical instruments that create and diffuse modes of thought', 96 which is precisely why Gramsci is so interested in the Rotary Club. Founded in

94 Q10II§61, Gramsci, Selections, pp. 117-8.

95 Q10II§61, Gramsci, Selections, pp. 117-8.

96 Joseph Femia, Gramsci's Political Thought (Oxford: Clarendon, 1987), p. 26. 
Chicago in 1905, it became an international organisation in 1912 with Clubs established in Winnipeg and London changing its name to the 'International Association of Rotary Clubs', and in 1922 to 'Rotary International'. ${ }^{97}$ As Gramsci observes, of the 2,639 Clubs in 1928, the overwhelming majority were in the US $(2,088)$, though he follows the international diffusion in detail: 254 Clubs in England, 85 in Canada, 20 in Cuba, 19 in Mexico, 18 Italy, 13 France, 1 Germany, 15 Australia, etc....

The Rotary Club is important for a number of reasons. Initially, Gramsci seems most concerned with what the reactions to the Rotary Club reveals about struggles within the Roman Catholic Church. The first note that bears the title, 'Rotary Club', follows a note concerning the war between the 'Catholic integralists' representing a 'European current of Catholicism' and the Jesuits. ${ }^{98}$ Gramsci discusses how while the Church has not taken an official stance with regard to the Rotary Club, '[t]he Jesuits object to the Rotary's links with Protestantism and Freemasonry, in it they perceive an instrument of Americanism and therefore an anti-Catholic mentality, to say the least. ${ }^{99}$ Yet he observes that central to the Rotary is its openness, 'everyone can join it'; unlike the Masons, the Rotary is not denominational, nor secret, nor elite. This sensibility was accompanied by an agenda of disseminating 'a new capitalist spirit', replacing the 'capitalism of plunder' with the 'idea that industry and trade are a social service even prior to being a business ...'; as per their motto, which Gramsci quotes, 'To give of oneself before thinking of oneself.'

After identifying its international structure, Gramsci argues that ' $[\mathrm{t}] \mathrm{he}$ Rotary Club is an organisation of the upper classes, and it does not address itself to the people, except indirectly. It is an essentially modern organization.' He then dissects its similarities and differences with the Catholic Church, Protestant Churches, and the Masons. ${ }^{101}$ Here Gramsci is a little more careful and analytic than in his later, blunter, rendition which is probably better known to the English-reading audience. In his notes on 'Americanism and Fordism', he writes in a quite fragmentary fashion, 'Rotary is Free Masonry without the petit bourgeois and without the petit-bourgeois mentality. America has Rotary and the YMCA; Europe has Free Masonry and the Jesuits. Attempts to introduce the YMCA into Italy; help given by Italian industry to these attempts (financial aid from Agnelli and the violent reaction of the Catholics)'. ${ }^{102}$

In the earlier more detailed notes, Gramsci focuses on the manner in which the international organisation is distinct from, and in a degree of tension with, its national chapters, 'as Rotarians from foreign countries have acknowledged, the Italian Rotary has its own specific character, in keeping with the local situation'. Gramsci even quotes The Rotary Wheel stating that '[o]ne gets the impression that in Italy the Rotary is not in step with us ... It seems to be different, more like a first cousin

97 Interestingly, Gramsci states that it started as a 'national institution' but became an international association in 1910 with a deposit of invested capital, in compliance with the laws of the State of Illinois, see Q5\$2, Gramsci, Prison Notebooks, Volume 2, p. 270. Gerratana confirms what Gramsci himself notes, that this information is from an article in La Civiltà Cattolica (21 June 1928), although the defining of it as an international organisation based on its economic activity instead of its legal selfproclamation fits well within Gramsci's analysis as we shall see.

98 Q5\$1, Gramsci, Prison Notebooks, Volume 2, pp. 267-9.

99 Q5\$2, Gramsci, Prison Notebooks, Volume 2, p. 269.

100 Two notes later, Gramsci makes the provocative suggestion of further study of the ideological nexuses between Americanism and Saint-Simonism whereby 'Rotarianism would be a modern Saint-Simonism of the right', Q5§4, Gramsci, Prison Notebooks, Volume 2, p. 273.

101 Q5§2, Gramsci, Prison Notebooks, Volume 2, p. 273.

102 Q22\$2, Gramsci, Selections, p. 286. 
than a brother ... but their ultimate objective is the same as ours' and that 'their Rotary is the only Rotary possible in Italy'. ${ }^{103}$ Gramsci compares the international organisation of the Rotary with its national clubs to the Catholic Church, expanding his earlier research on the Catholic treatment of the Rotary which Gramsci explains in part by noting '[i]n countries where Catholics are not in the majority, the Jesuits demand religious tolerance ...' whereas '[i]n Catholic countries ... [they] require an all-out struggle against the amorphous institutions that provide a favorable terrain for non-Catholics in general'. ${ }^{104}$

Gramsci uses the major themes of this analysis from Notebook 5 when he raises the Rotary Club both in the special notebook on Machiavelli (Q13) and Americanism and Fordism (Q22). These passages give more specific content to, for example, his discussion of 'organic centralism' and 'democratic centralism' when he calls for further study on their manifestations 'in State life ...; in interstate life (alliances, various forms of international political "constellation"); in the life of political and cultural associations (Freemasonry, Rotary Club, Catholic Church) and of tradeunion and economic ones'. ${ }^{105}$ The notion that Gramsci's analysis of Italy was not deeply rooted in the international arena is undermined by passages such as:

It is also necessary to take into account the fact that international relations intertwine with these internal relations of nation-states, creating new, unique and historically concrete combinations ... Religion, for example, has always been the source of such national and international ideological-political combinations, and so too have other international organisations - Freemasonry, Rotarianism, the Jews, career diplomacy. ${ }^{106}$

With the Rotary Club, as with so many of Gramsci's investigations, connections quickly envelop what at first seem like entirely unrelated discussions, such as those between the Rotary Club and philosophical currents that influence common sense, specifically pragmatism, as well as related methodological considerations. ${ }^{107}$ While pursuing these connections would take us beyond the scope of this project, these considerations illustrate that Gramsci's conception of civil society, far from adhering narrowly to the national, operates across domestic/international boundaries to affect political practices. Indeed, his analysis extends further to assess the ethico-political claims and class-biases of such interactions.

\section{Conclusion}

Our hope is that this article will contribute to debates over the utility of Gramsci's work for the analysis of international politics. We have examined the grounds on which critics have questioned the use of Gramsci for understanding International Relations. These critiques generally rest on the premise that Gramsci's political theory was formulated around 'national' categories that preclude the international albeit for different reasons. Some critics believe his work was always grounded in domestic considerations, others see him as arriving there having begun at a more international point of departure. In reaching similar conclusions, these differences in

103 Q5\$61, Gramsci, Prison Notebooks, Volume 2, p. 319.

104 Q5\$61, Gramsci, Prison Notebooks, Volume 2, pp. 318-19.

105 Q13\$36, Gramsci, Selections, p. 188.

106 Q13\$17, Gramsci, Selections, p. 182.

107 Q17\$22, Gramsci, Selections, pp. 372-3. 
orientation contain diverse assessments of Gramsci's politics and methods. Some insist that neo-Gramscian appropriations fail to recognise the overall incoherence of his work. They invoke secondary literature outside of IR to insist on a 'symptomatic' reading. This position, as we have shown, itself fails to appreciate the partisan nature of the symptomatic reading and much of the secondary literature on Gramsci, which is being re-evaluated as the corpus of his work becomes more completely available to Anglophone readers. Other critics are less concerned with insisting upon a symptomatic reading, but argue that Gramsci's work abandoned the international because he could no longer theorise it after the failures of working class political action in Western Europe, either due to the inadequacy of his analysis or an abandonment of his Marxian commitments. As we have also shown, these readings miss key aspects of Gramsci's contributions, such as the originality of his conception of hegemony and his project of rereading of liberal political categories through a Marxian lens. Equally significantly, these two veins of critique of Gramsci's limitations vis-à-vis understanding the international fail to appreciate the extent to which Gramsci's analytical categories already contain a logic of the international. Foundational concepts to which critics appeal as illustrations of the inherently 'domestic' focus Gramsci's work - such as the (nation-)state, the 'national-popular', and civil society - are presented by Gramsci as involving multiple 'levels of analysis', as the philological analysis above demonstrates. Thus, key institutions of civil society like the Catholic Church and the Rotary Club are precisely analysed by Gramsci in their international and national dimensions. Our illustration of this focused on the Rotary Club to highlight Gramsci's method of seeing the national and the international as analytically distinguishable but inter-related. This kind of analysis challenges the dominant presumption of a strict disjuncture between the domestic and international. In this sense, Gramsci's work resists a neat correspondence with what is often understood to be a central project for International Relations, 'developing a theory of the international'. As we have argued, Gramsci provides a rather different foundation from which to critique and reread such projects' very ontological premises. 